\title{
Perceptional Analysis of Msmes Tax Justice Aspect
}

\author{
Fransiscus X N Susanto ${ }^{1}$, David A A Pesudo ${ }^{2}$, Michael Victor Warouw ${ }^{3}$
}

1,2,3 Satya Wacana Christian University, Indonesia

\section{A R T I C L E I N F O}

Article history:

Received 18 July 2020

Received in revised form

25 July 2020

Accepted 18 August 2020

Available online 29 August 2020

Keywords:

SMEs, Tax Justice, Tax

Complience

\begin{abstract}
A B S T R A C T
This study aims to identify how the role of tax justice for taxpayer of Small and Medium sized enterprises (SMEs) will affect the level of compliance with paying taxes. The results of this study are also useful for Direktorat Jendral Pajak to identify how SMEs react to these policies so that they can represent the condition of their business in their obligation to pay taxes. This study used a qualitative method with a descriptive approach through questionnaires and in-depth interviews with respondents. The population of this study was SMEs assisted by Dinas Koperasi dan UMKM kota Salatiga with 1,656 business units with the method of determining many samples using the slovin formula measurement and with convenience sampling. The impact of the application of PP 23 of 2018 has been felt by taxpayer of SMEs since July 2018 , the reduction in tax rates by half a percent of the previous tax rate
\end{abstract} has been proven to increase tax compliance for taxpayers of SMEs but the application of PP 23 of 2018 does not affect tax compliance for taxpayers of SMEs who have previously obeyed and taxpayer of SMEs with the motive to pay certain taxes. 


\section{Introduction}

The development of Income Tax on Indonesian Micro Small and Medium Enterprises (MSMEs) was regulated per 2013 through Government Regulation (GR) number 46 of 2013. This regulation was enacted to simplify the calculation of tax cost (Herman et al., 2013), create efficiency and reduce the administrative cost of Taxpayers and Directorate General of Taxation and optimizing tax revenue by expanding the base into the MSME sector. This tax rates is final with tariff about 1 percent of monthly urnover and requires taxpayers to pay their taxes in a profit or loss situation and the losses suffered by taxpayers cannot be credited (Pratiwi et al., 2018; Wulandari \& Budiaji, 2018). Research from (Aneswari et al., 2013) concluded that GR number 46 of 2013 violates the principle of tax justice because the tax object is directly charged to its turnover regardless of the profit margin that Taxpayers gets. This implementation of GR number 46 of 2013 raises pros and cons.

Accordance to above, President Joko Widodo announced the update of GR number 46 of 2013 to GR number 23 of 2018 on June $22^{\text {nd }}, 2018$. The tax tariff decrease to 0.5 percent of monthly turnover with the condition that taxpayers have an accumulated turnover per year not exceeding than 4.8 billion rupiahs per year without deducting expenses or costs related to the business they are running and still in the form of final income tax as before.

The perception of fairness in taxation system can creates significantly affect compliance in meeting tax obligations and reduce tax avoidance (Faizal et al., 2017; E. R. Yulianti, 2019). The dimension of tax justice is a non-economic variable as a key to tax compliance behavior. There are five dimensions of tax justice including (1) the level of general fairness and distribution of the tax cost; (2) Exchange with government; (3) Personal interest; (4) Special provisions; (5) Tax rate structure (Andayani, 2018).

There are several studies that link the dimensions of justice with tax compliance developed from research by (Dewi et al., 2018; Fitria \& Supriyono, 2019; Sari, 2017; Suryadi, 2018), with the results stating that the dimension of justice affects the compliance of MSME taxpayers.

This study aims to see how the perception of taxpayers towards fairness and tax compliance in GR number 23 of 2018. This research was conducted at the MSME assisted by the Department of Cooperatives and SME in Salatiga City. As of September 2017, the total actors and their classification can be seen in the Table 1.

Table 1. Classification and Quantity of MSME Assisted by Department of Cooperative and SME Salatiga

\begin{tabular}{lc}
\hline Business clasification & Number of actors \\
\hline Agriculture, Animal Husbandry, Forestry and Fisheries & 216 \\
Mining and Excavation & 5 \\
Processing Industry & 614 \\
Electricity, Gas and Clean Water & 2 \\
Construction & 20 \\
Trade, Hotel and Restaurant & 613 \\
Transportation and Communication & 1 \\
Finance, Leasing, and Corporate Services & 21 \\
Others & 164 \\
\hline Total & $\mathbf{1 . 6 5 6}$ \\
\hline
\end{tabular}

Source: Dinas Koperasi dan UMKM kota Salatiga

\section{Methods}

This research used qualitative methods with a descriptive approach. The purpose of this study is to find out about the role of tax justice dimension in its effect on the level of compliance of MSME Taxpayers based on the decreasing phenomenon of MSME tax rates according to GR number 23 of 2018.

Information data in this study was obtained directly from the taxpayers actors in Salatiga as research informants, and the secondary data taken from Pratama Tax Office Salatiga. The sample population were 1,656 MSMEs assisted by the Department of Cooperatives and SME Salatiga with the criteria as (1) having Tax ID and (2) paying taxes using GR number 46 of 2013 or having used GR tax number 23 of 2018. Determination of the sample used covenience sampling with Slovin formula. The results of these calculations produce 95 MSMEs as a suitable sample to be respondents. 
The questionnaire than been distributed is the result of a modification from similar research by (Azmi \& Perumal, 2008; Wulandari \& Budiaji, 2018) and then conducted several interviews with MSME informants who has special characteristics in Salatiga such as (1) Taxpayers with high Net Profit Margin (NPM), (2) Taxpayers with low NPM, (3) Taxpayers with high turnover, (4) Taxpayers with low turnover, (5) The longest taxpayers in carrying out tax obligations, and (6) New Taxpayers who registered themselves as taxpayers between June 2018 until December 2018.

\section{Results and Discussions}

\section{Results}

Table 2. Total respondent data and respondent's business classification

\begin{tabular}{clcc}
\hline Business classification code & \multicolumn{1}{c}{ Business Type } & Frequency & Percentage \\
\hline 1 & Retail & 40 & $42 \%$ \\
2 & Services and others & 16 & $17 \%$ \\
3 & Manufacture & 10 & $11 \%$ \\
4 & Hotel and Boarding House & 3 & $3 \%$ \\
5 & Garage & 4 & $4 \%$ \\
6 & Cooperative & 5 & $5 \%$ \\
7 & Transportation & 3 & $3 \%$ \\
8 & Culinary & 14 & $15 \%$ \\
\hline
\end{tabular}

From the 95 respondents who used the GR number 23 of 2018 tax, retail businesses dominated by 42 percent, followed by transportation, hotel and boarding businesses as respondents with at least 3 percent.

Table 3. Demographics of respondents

\begin{tabular}{|c|c|c|}
\hline & Frequency & Percentage \\
\hline \multicolumn{3}{|l|}{ Gender } \\
\hline Men & 61 & $64.2 \%$ \\
\hline Women & 34 & $35.8 \%$ \\
\hline Total & 95 & $100 \%$ \\
\hline \multicolumn{3}{|c|}{ Age Classification } \\
\hline Age 20 - 25 & 16 & $16.8 \%$ \\
\hline Age $26-30$ & 12 & $12.6 \%$ \\
\hline Age $31-35$ & 14 & $14.7 \%$ \\
\hline Age $36-40$ & 16 & $16.8 \%$ \\
\hline Age $>40$ & 37 & $38.9 \%$ \\
\hline Total & 95 & $100 \%$ \\
\hline \multicolumn{3}{|c|}{ Last Education } \\
\hline SLTA & 30 & $31.6 \%$ \\
\hline D3 & 2 & $2.1 \%$ \\
\hline S1 & 51 & $53.7 \%$ \\
\hline $\mathrm{S} 2$ & 1 & $1.1 \%$ \\
\hline Others & 11 & $11.6 \%$ \\
\hline Total & 95 & $100 \%$ \\
\hline \multicolumn{3}{|l|}{ Tax ID Time } \\
\hline 1 - 5 Year & 56 & $58.9 \%$ \\
\hline 6 - 10 Year & 21 & $22.1 \%$ \\
\hline 11 - 15 Year & 6 & $6.3 \%$ \\
\hline >15 Year & 12 & $12.6 \%$ \\
\hline Total & 95 & $100 \%$ \\
\hline \multicolumn{3}{|c|}{ Type of Taxpayer } \\
\hline Institution & 14 & $14.7 \%$ \\
\hline Private & 81 & $85.3 \%$ \\
\hline Total & 95 & $100 \%$ \\
\hline
\end{tabular}




\section{Business Classification}

\begin{tabular}{lcc} 
Micro & 64 & $67.4 \%$ \\
Small & 28 & $29.5 \%$ \\
Medium & 3 & $3.2 \%$ \\
Total & 95 & $100 \%$ \\
\hline
\end{tabular}

The research respondents were dominated by men, with total amount to 64.2 percent of the total respondents and the remaining 35.8 percent were women. Then age over 40 years old dominated the age clasification, followed by age at the range of 26-30 years old. Judging from the level of education, the Bachelor education level dominates as much as 53.7 percent of the total respondents, then last occupation is the Master level at 1.1 percent. The business classification is dominated by micro enterprises with total 64 units of the total respondents and most recently occupied by medium enterprises as many as 3 units.

Table 4. Distribution of Average Answers from Respondents to the Dimensions of Tax Justice - General Justice Level in Government Regulation 23 of 2018

\begin{tabular}{|c|c|c|c|c|c|c|c|c|c|c|}
\hline \multicolumn{2}{|r|}{ Dimensions of General Justice } & \multicolumn{9}{|c|}{ Average of Respondents per Business Classification } \\
\hline No. & Statement & 1 & 2 & 3 & 4 & 5 & 6 & 7 & 8 & Average \\
\hline 1 & $\begin{array}{l}\text { Personally, I believe that the income } \\
\text { tax system in Indonesia is fairly } \\
\text { regulated. }\end{array}$ & 3.47 & 3 & 3.7 & 3.33 & 3.75 & 3.6 & 3.66 & 3.57 & 3.45 \\
\hline 2 & $\begin{array}{l}\text { In general, we believe that the way } \\
\text { of imposing income tax is applied } \\
\text { fairly to each taxpayer. }\end{array}$ & 3.57 & 3.25 & 3.5 & 3.66 & 3.5 & 3.8 & 4.33 & 3.42 & 3.52 \\
\hline 3 & $\begin{array}{l}\text { In general, we feel the current } \\
\text { income tax charged on our business } \\
\text { is fair. }\end{array}$ & 3.55 & 3.37 & 3.7 & 3.66 & 3.75 & 3.8 & 4.33 & 3.78 & 3.62 \\
\hline 4 & $\begin{array}{l}\text { I feel that the imposition of income } \\
\text { tax on MSMEs through GR } 23 \text { of } \\
2018 \text { has been charged fairly. }\end{array}$ & 4.15 & 3.87 & 4.3 & 4 & 4.25 & 4.2 & 4.33 & 4.21 & 4.13 \\
\hline
\end{tabular}

In general, Indonesia's tax system is considered fair. Seven of the eight sectors stated that GR number 23 of 2018 was considered fairer than its predecessor supported by one of the arguments in sector 7:

"Taxes are now cheaper, the cost tariff is not easy to predict because it is related to traffic, so the savings in tax cost can be diverted to pay expenses or replace spare parts for business continuity".

Table 5. Distribution of Average Answers from Respondents to the Dimensions of Tax Justice - Exchange with government in GR 23 of 2018

\begin{tabular}{|c|c|c|c|c|c|c|c|c|c|c|}
\hline & \multirow{2}{*}{$\begin{array}{c}\text { Exchange with Government } \\
\text { Statement }\end{array}$} & \multicolumn{9}{|c|}{ Average of Respondents per Business Classification } \\
\hline No. & & 1 & 2 & 3 & 4 & 5 & 6 & 7 & 8 & Average \\
\hline 1 & $\begin{array}{l}\text { The businesses we run receive } \\
\text { appropriate and fair feedback from } \\
\text { the government for the payment of } \\
\text { income tax that we have paid, } \\
\text { For example: infrastructure, ease of } \\
\text { carrying out company activities } \\
\text { related to regulations and } \\
\text { bureaucracy, public facilities. }\end{array}$ & 3.82 & 3.43 & 3.8 & 4 & 4 & 3.6 & 4 & 3.42 & 3.7 \\
\hline 2 & $\begin{array}{l}\text { Benefit that our business receive } \\
\text { from the government as an } \\
\text { exchange for the tax payment of GR } \\
23 / 2018\end{array}$ & 3.8 & 3.18 & 3.7 & 4 & 3.75 & 3.6 & 4.66 & 3.42 & 3.65 \\
\hline 3 & $\begin{array}{l}\text { Tax GR } 23 \text { number } 2018 \text { that we } \\
\text { pay is too high when compared to } \\
\text { the benefits / exchange provided by } \\
\text { the government. }\end{array}$ & 2.37 & 2.75 & 2.4 & 1.66 & 2 & 2.8 & 1 & 2.78 & 2.44 \\
\hline
\end{tabular}


On average, each sector has received an appropriate exchange when compared to the amount of tax paid based on the reduction in taxes through tax policy stated at GR number 23 year 2018. Sector 7 is the sector that gives the highest score with the support of arguments as below:

"The construction of toll roads now is very helpful for our business, considering that we can saving the time consume and reduced the risks".

Table 6. Distribution of Average Answers from Respondents to the Dimensions of Tax Justice Personal Interests in Government Regulation 23 of 2018

\begin{tabular}{|c|c|c|c|c|c|c|c|c|c|c|}
\hline \multicolumn{2}{|r|}{ Personal interests } & \multicolumn{9}{|c|}{ Average of Respondents per Business Classification } \\
\hline No. & Statement & 1 & 2 & 3 & 4 & 5 & 6 & 7 & 8 & Average \\
\hline 1 & The current Government Regulation & & & & & & & & & \\
\hline & $\begin{array}{l}23 \text { of } 2018 \text { requires our businesses } \\
\text { to pay more than an appropriate / } \\
\text { fair share of income tax. }\end{array}$ & 1.97 & 1.87 & 2 & 2 & 1.75 & 1.6 & 1.33 & 1.92 & 1.9 \\
\hline 2 & $\begin{array}{l}\text { Compared to other taxpayers, our } \\
\text { business pays less income tax than } \\
\text { a fair share of income tax. }\end{array}$ & 2.6 & 2.62 & 3.2 & 2.66 & 3 & 2.6 & 2.66 & 2.78 & 2.71 \\
\hline 3 & $\begin{array}{l}\text { Compared to the amounts paid by } \\
\text { other Taxpayers, our business pays } \\
\text { higher income tax than a fair share } \\
\text { of income tax. }\end{array}$ & 3.27 & 3 & 2.9 & 3.33 & 3 & 3.4 & 3.66 & 3.14 & 3.17 \\
\hline
\end{tabular}

The average result of respondents is around number 3 (neutral) because 63 out of 95 respondents stated that they never compared the amount of tax paid with other taxpayers. The rest stated that they paid more than other taxpayers for the same reasons:

"My business located in a central area, which in fact the products that I sell and the level of product sales are relatively the same, but why am I the only one being visited by the Tax Officer regarding tax payments".

Table 7. Distribution of Average Answers from Respondents to the Dimensions of Tax Justice - Special Provisions in Government Regulation 23 of 2018

\begin{tabular}{|c|c|c|c|c|c|c|c|c|c|c|}
\hline \multicolumn{2}{|r|}{ Special Provisions } & \multicolumn{9}{|c|}{ Average of Respondents per Business Classification } \\
\hline No. & Statement & 1 & 2 & 3 & 4 & 5 & 6 & 7 & 8 & Average \\
\hline 1 & $\begin{array}{l}\text { Special provisions that are only given } \\
\text { to certain taxpayers are unfair. } \\
\text { For example: there is a non-taxable } \\
\text { income calculation in the income tax } \\
\text { calculation of employee. }\end{array}$ & 3.47 & 3.5 & 3.5 & 3.66 & 3.75 & 3.8 & 3 & 3.35 & 3.48 \\
\hline 2 & $\begin{array}{l}\text { Taxpayers, who have the same income } \\
\text { as our company, must pay income tax } \\
\text { of the same amount. These income } \\
\text { taxes are levied regardless of the } \\
\text { investments they make, the } \\
\text { dependents they have, or other } \\
\text { financial obligations. }\end{array}$ & 2.65 & 2.75 & 2.7 & 2.33 & 2 & 3.2 & 2 & 3 & 2.69 \\
\hline
\end{tabular}

An average score between two and three are disagree and neutral. Respondents disagreed with the elimination of the operating expense element in the calculation of GR number 23 of 2018. The parties that are most disadvantaged in implementing GR number 23 of 2018 is sector 6 (Cooperatives) which is dominated by Savings and Loans Cooperatives, according to source 5 in sector 6 stated:

"Our income comes from loan interest and admin fees only. We must compete in the amount of interest and admin fees with other cooperatives, which forces us to set interest and admin fees that are competitive with the market. Plus we have to pay employees and other operating expenses." 
Table 8. Distribution of Average Answers from Respondents to the Dimensions of Tax Justice - Tax Rate Structure in Government Regulation 23 of 2018

\begin{tabular}{|c|c|c|c|c|c|c|c|c|c|c|}
\hline \multirow{2}{*}{\multicolumn{2}{|c|}{$\begin{array}{c}\text { Tax Rate Structure } \\
\text { Statement }\end{array}$}} & \multicolumn{9}{|c|}{ Average of Respondents per Business Classification } \\
\hline & & 1 & 2 & 3 & 4 & 5 & 6 & 7 & 8 & Average \\
\hline 1 & $\begin{array}{l}\text { High income earners have an ability to } \\
\text { pay higher income tax, so it is only } \\
\text { natural that they pay higher income tax } \\
\text { than those charged to low income } \\
\text { recipients. }\end{array}$ & 4.25 & 4.12 & 4 & 4 & 4.25 & 4 & 4 & 4.28 & 4.17 \\
\hline 2 & $\begin{array}{l}\text { A fair tax rate means that it must be the } \\
\text { same for every SME taxpayer, be it } \\
\text { Micro, Small or Medium Enterprises. }\end{array}$ & 2.425 & 2.31 & 2.2 & 3 & 2 & 3 & 3.33 & 2.71 & 2.48 \\
\hline
\end{tabular}

Most respondents disagreed if the tax rate was equalized in each group of MSMEs. Five of the eight sectors gave a score of 2 where the MSME grouping according to Law No. 20 of 2008 was grouped according to annual turnover and total investment it owned. Micro MSMEs with a turnover of below 300 million per year have different economic strengths from medium MSMEs with a turnover of between 2.5 billion to 4.8 billion per year. There should be a difference in tax rates between MSME groups, as conveyed by resource person 4 in sector 1 ,

"There should be differences in rates between groups of MSMES, such as the application of PAM payments where the faster the water debit, the more expensive the payment. The MSMEs that have high turnover should be subject to higher taxes and Micro MSMEs which are actually just starting a business and do not yet have income stability and are still in the shadow of a loss should not be taxed ".

Table 9. Distribution of Average Answers from Respondents to Tax Compliance in PP 23 of 2018

\begin{tabular}{|c|c|c|c|c|c|c|c|c|c|c|}
\hline \multicolumn{2}{|r|}{ Tax Compliance } & \multicolumn{9}{|c|}{ Average of Respondents per Business Classification } \\
\hline No. & Statement & 1 & 2 & 3 & 4 & $\mathbf{5}$ & 6 & 7 & 8 & Average \\
\hline 1 & $\begin{array}{l}\text { I pay the income tax according to } \\
\text { the provisions because I realize that } \\
\text { it is an obligation as an Indonesian } \\
\text { citizen. }\end{array}$ & 4.05 & 4 & 4.3 & 4 & 4.75 & 4.2 & 4 & 4.14 & 4.11 \\
\hline 2 & $\begin{array}{l}\text { I pay taxes on time and } \\
\text { trying to minimize late payments. }\end{array}$ & 4.2 & 3.81 & 4.1 & 4.66 & 4.25 & 4.2 & 4.33 & 4.14 & 4.13 \\
\hline 3 & $\begin{array}{l}\text { I will tend to comply more with } \\
\text { existing tax regulations because the } \\
\text { MSME income tax rate has fallen } \\
\text { from } 1 \% \text { to } 0.5 \% \text { of turnover. }\end{array}$ & 3.77 & 3.87 & 3.4 & 3 & 3.5 & 3.2 & 3 & 3.92 & 3.68 \\
\hline 4 & $\begin{array}{l}\text { I will tend to comply more with } \\
\text { existing tax regulations. I pay taxes } \\
\text { regularly because I use my own tax } \\
\text { calculation management because } \\
\text { the MSME income tax rate has } \\
\text { dropped from } 1 \% \text { to } 0.5 \% \text { of } \\
\text { turnover. }\end{array}$ & 4.17 & 3.68 & 4 & 4 & 4.25 & 4.4 & 4.33 & 4.07 & 4.07 \\
\hline 5 & $\begin{array}{l}\text { Taxpayers should pay taxes on time } \\
\text { and do the calculation themselves } \\
\text { so that regional revenues are more } \\
\text { effective. }\end{array}$ & 3.85 & 3.43 & 3.7 & 4.33 & 4.25 & 3.6 & 4.33 & 3.64 & 3.76 \\
\hline
\end{tabular}

The score for each sector is more than 4 indicating the form of compliance to pay taxes. It can be seen in table 9 that the respondent pays taxes on time according to his own calculations with an average score in all sectors of more than 4 . For statement number five in table 9 when compared to the exchange dimension of the government, it has a positive correlation when the respondent gets exchange in accordance with expectations, the respondent is also more orderly in paying taxes.

The existence of GR number 23 of 2018 makes 5 out of 8 MSME sectors more likely to comply with tax regulations due to lower tax rates. Informant 1 in sector 2 gave reasons: 
"The government has tried to reduce the amount of tax that we have to pay, at least the feedback we can give is to pay more orderly on time and pay the amount of taxes that should be".

\section{Discussion}

Five dimensions of tax justice are used in assessing perceptions of justice and compliance with GR number 23 of 2018. Research belonging (Dewi et al., 2018; Faizal et al., 2017; Fitria \& Supriyono, 2019; Sari, 2017; Suryadi, 2018; Syahdan, S. A. \& Rani, 2014) show that the perception of the dimension of justice has a significant influence on tax compliance. On the other hand, (A. Yulianti \& Kurniawan, 2019) argue that the dimension of justice has no effect on compliance because of trust issue in the government. The results of this study alone show several results in each of its dimensions due to there are dimensions that are not relevant to the conditions of the MSME Taxpayers in Salatiga that caused they cannot represent it.

\section{Perceptions of Justice Over General Justice}

(Purba et al., 2018; Wardani et al., 2015; Wulandari \& Budiaji, 2018) suggest that the perception of general justice has a significant effect on the compliance of taxpayers and this is inversely proportional to what was stated by (Anwar, 2018). The results show that in general the Indonesian general taxation system felt by the MSME Taxpayers in Salatiga is better. However, research conducted by (Nurpratiwi, A. et al., 2014) also with (Syahdan, S. A. \& Rani, 2014) stated that the system and the imposition of the previous tax GR number 46 of 2013 was considered unfair, so GR number 23 of 2018 was more successful in creating justice for taxpayers.

\section{Perceptions of Justice on Government Exchange}

MSME Taxpayers in Salatiga agrees that the government's exchange reflects fairness in taxation. Pris (Azmi \& Perumal, 2008; Yadinta et al., 2018), show that MSME Taxpayers felt the exchage with government in accordance with their expectations is important so that they do not mind being orderly carry out their tax obligations.

\section{Perceptions of Justice of Personal Interests}

In this dimension, the results show that Salatiga UMKM Taxpayers have less personal interest because they pay their taxes without ever comparing the amount of taxes that they pay with other taxpayers. Taxpayers consider that the dimension of personal interest cannot be used as a measure of compliance because binding regulations are taken more into consideration than their personal interests (Suryadi, 2018).

\section{Perceptions of Justice of Special Provisions}

Respondents still have objections to the provisions of GR number 23 of 2018 imposition that use turnover to ignore the cost borne by the taxpayers. For example, there are some sectors that have low NPM and have operating expenses that must be paid, such as cooperatives. In line with previous research, even though these special provisions are burdensome, they still pay this obligation not because of certain relief but because of binding regulations (Suryadi, 2018).

\section{Perceptions of Justice of Tax Rate Structure}

MSME Taxpayers does not agree with GR number 23 of 2018 in uniforming rates in each group of MSMEs. There should be differences in tax rates between MSMEs groups. Taxpayers compliance is not based on a tariff structure but is more oriented to the rules and sanctions that apply. The results are in line with research by (Fitria \& Supriyono, 2019; Suryadi, 2018; Wardani et al., 2015) although the tariffs fluctuate, compliance with obligations is still carried out. This is different from what was stated by (Julianto, 2017; Lazuardini et al., 2016) where the tax rate has a significant positive effect on compliance.

\section{Conclusion}

Based on the results of the study, it can be concluded that the perception of justice for GR number 23 of 2018 is considered fairer than GR number 46 of 2013. The dimensions of the perception of justice in MSME Taxpayers in Salatiga are not so significant in shaping the compliance of taxpayers. The formation of awareness in paying taxes is more influenced by education and socialization of tax benefits and the clarity of the use of funds in return for taxpayers from the government with the ease of payment mechanisms and regulations on tax determination, as well as the imposition of strict sanctions against tax offenders. The limitation of this study is the difference in the number of respondents from each segment 
and sector of MSME TP due to the use of convenience sampling method. In addition, it is seen that it does not reflect the overall condition of the MSME TP in Indonesia because of the limitation. Based on the results of the research, suggestions that can be given for further research are that the number of research respondents should be the same for each segment of MSMEs and for each sector with the purposive sampling method.

\section{References}

Andayani, E. (2018). Pengaruh Faktor-Faktor Pelaksanaan Pp 46 Tahun 2013 Terhadap Kepatuhan Wajib Pajak Umkm (Studi Kasus Umkm Pusat Grosir Tanah Abang Jakarta Pusat). Transparansi Jurnal Ilmiah Ilmu Administrasi, 1(1), 12-28. https://doi.org/https://doi.org/10.31334/trans.v1i1.137

Aneswari, Y. R., Darmayasa, I. N., Yusdita, E. E., Kesuma, S., Blitar, N., No, J. M., \& Kidul, K. (2013). Kata kunci: Keadilan, Kepatuhan Pajak, Kritis, PPh 1\%.1-22.

Anwar, D. R. (2018). Pengaruh norma subjektif, keadilan perpajakan, religiusitas, dan self efficacy terhadap kepatuhan wajib pajak orang pribadi. 1-108. https://doi.org/https://dspace.uii.ac.id/handle/123456789/7710

Azmi, A. A., \& Perumal, K. A. (2008). Tax Fairness Dimensions in an Asian Context: The Malaysian Perspective. International Review of Business, 4(5), 11-19. https://doi.org/https://www.researchgate.net/profile/Anna_Che_Azmi/publication/242288892_Ta x_Fairness_Dimensions_In_An_Asian_Context_The_Malaysian_Perspective/links/5600136508aec948 c4fa6455.pdf.

Dewi, N. K., Tirtayani, L. A., \& Kristiantari, R. (2018). Pengaruh Metode Bermain Peran Terhadap Kemampuan Sosial Anak Kelompok B di Paud Gugus Anggrek, Kuta Utara. Journal Pendidikan Anak Usia Dini Universitas Pendidikan Ganesha, 6(1), 43-53.

Faizal, S. M., Palil, M. R., Maelah, R., \& Ramli, R. (2017). Perception on justice, trust and tax compliance behavior in Malaysia. Kasetsart Journal of Social Sciences, 38(3), 226-232. https://doi.org/https://doi.org/10.1016/j.kjss.2016.10.003

Fitria, P. A., \& Supriyono, E. (2019). Pengaruh Pemahaman Peraturan Perpajakan, Persepsi Tarif Pajak, Dan Keadilan Perpajakan Terhadap Kepatuhan Wajib Pajak. ECONBANK: Journal of Economics and Banking, 1(1), 47-54. https://doi.org/https://doi.org/10.35829/econbank.v1i1.7

Herman, O., Hidayah, N., \& Raharja, L. (2013). Peranan Usaha Mikro Kecil Dan Menengah Dalam Pembangunan Ekonomi Indonesia Melalui Pajak (Peraturan Pemerintah No. 46 Tahun 2013). JP Fakultas Ekonomi Dan Bisnis Unsoed, 3(46).

Julianto, A. (2017). Pengaruh Tarif, Sosialisasi Serta Pemahaman Perpajakan Terhadap Kepatuhan Wajib Pajak UMKM Di Kota Semarang. Jurnal Fakultas Ekonomi Dan Bisnis Universitas Dian Nuswantoro Semarang.

Lazuardini, E. R., S., H. J., \& Priyono, A. A. (2016). Pengaruh Pemahaman Peraturan Perpajakan, Tarif Pajak Dan Sanksi Pajak Terhadap Kepatuhan Wajib Pajak UMKM (Studi Pada Wajib Pajak Orang Pribadi Yang Terdaftar di KPP Pratama Malang Selatan). E - Jurnal Riset ManajemenPRODI MANAJEMEN, 7(1). https://doi.org/https://doi.org/10.1123/ijsb.8.1.1

Nurpratiwi, A., Saifi, M., \& Budiharjo, O. (2014). Analisis Persepsi Wajib Pajak Pemilik Umkm Terhadap Penetapan Kebijakan Pajak Penghasilan Final Sesuai Peraturan Pemerintah No. 46 Tahun 2013 (Studi Pada Kpp Pratama Malang Utara). Jurnal Mahasiswa Perpajakan. Jurnal Mahasiswa Perpajakan,

2(1). https://doi.org/http://perpajakan.studentjournal.ub.ac.id/index.php/perpajakan/article/view/26

Pratiwi, K. Y., Rasana, I. D. P. R., \& Pudjawan, K. (2018). Pengaruh Model Pembelajaran Teams Games Tournament ( Tgt ) Terhadap Penguasaan Kosakata Bahasa Inggris Siswa Kelas Iv Sd Gugus Iv Kecamatan Tabanan. JJPGSD, 1(1).

Purba, I. C., Ilat, V., \& Gamaliel, H. (2018). Pengaruh Reinventing Policy, Sikap Rasional, Dan Keadilan Pajak Terhadap Kepatuhan Wajib Pajak Orang Pribadi Di Kpp Pratama Manado. Going Concern: Jurnal Riset Akuntansi, 13(4), 235-243. https://doi.org/https://doi.org/10.32400/gc.13.03.20119.2018

Sari, M. A. (2017). Pengaruh Persepsi dan Persepsi Kemudahan Perpajakan Terhadap Kepatuhan Wajib Pajak Kelompok UMKM Pasa Penetapan Peraturan Pemerintah Nomor 46 Tahun 2013 (Studi pada 
KPP Pratama Lamongan ).

Suryadi, D. (2018). Pengaruh Dimensi Keadilan Pajak dan Tax Morale terhadap Tingkat Kepatuhan Wajib Pajak Badan yang Terdaftar di KPP Pratama Kota Bandung. https://doi.org/https://doi.org/10.13140/RG.2.2.24995.76329

Syahdan, S. A., \& Rani, A. P. (2014). Dimensi Keadilan Atas Pemberlakuan PP No. 46 Tahun 2013 Dan Peningkatan Kepatuhan Wajib Pajak. Jurnal InFestasi, 10(1), 64-72. https://doi.org/https://doi.org/10.21107/infestasi.v10i1.512

Wardani, E., Yuesti, A., \& Sudiartana, I. M. (2015). Dampak Dimensi Keadilan Pajak Terhadap Tingkat Kepatuhan Wajib Pajak Badan Dalam Konteks Tri Hita Karana Di KPP Pratama Badung Selatan. Jurnal Manajemen Dan Akuntansi STIE Triatma Mulya, 21(2), 99-112. https://doi.org/http://triatmamulya.ejurnal.info/index.php/triatmamulya/article/download/63/3 6.

Wulandari, S., \& Budiaji, A. (2018). Pengaruh Persepsi Keadilan Pajak Dalam Peraturan Pemerintah Republik Indonesia Nomor 46 Tahun 2013 Terhadap Kepatuhan Dalam Memenuhi Kewajiban Perpajakan. ISLAMICONOMIC: Jurnal Ekonomi Islam, 8(2), 239-268. https://doi.org/https://doi.org/10.32678/ijei.v8i2.71

Yadinta, P. A. F., Mulyadi, J., \& Suratno. (2018). Kualitas Pelayanan Fiskus , Dimensi Keadilan , Kesadaran Wajib Pajak dan Kepatuhan Wajib Pajak Orang Pribadi. Jurnal Riset Akuntansi Dan Perpajakan JRAP, $5(2)$,

201-212. https://doi.org/http://ujijurnal.univpancasila.ac.id/index.php/jrap/article/view/186

Yulianti, A., \& Kurniawan, A. (2019). Pengaruh Pengetahuan Perpajakan Dan Persepsi Keadilan Terhadap Tingkat Kepatuhan Wajib Pajak Melalui Kepercayaan. Jurnal Riset Keuangan Dan Akuntansi, 5(1). https://doi.org/https://doi.org/10.25134/jrka.v5i1.1929

Yulianti, E. R. (2019). Upaya Kepemimpinan Spiritual Dalam Mengembangkan Budaya Mutu Di Sma Plus $\begin{array}{llll}\text { Muthahhari Bandung. } & \text { SCHEMATA, } & \text { 128-151. }\end{array}$ https://doi.org/https://journal.uinmataram.ac.id/index.php/schemata/article/view/515 